(2) Open Access Full Text Article

\title{
Structure-activity relationship of an antimicrobial peptide, Phylloseptin-PHa: balance of hydrophobicity and charge determines the selectivity of bioactivities
}

This article was published in the following Dove Medical Press journal:

Drug Design, Development and Therapy

\author{
Yuzhang Liu',2,* \\ Qiang Du',* \\ Chengbang $\mathrm{Ma}^{2}$ \\ Xinping $\mathrm{Xi}^{2}$ \\ Lei Wang ${ }^{2}$ \\ Mei Zhou ${ }^{2}$ \\ James F Burrows ${ }^{2}$ \\ Tianbao Chen ${ }^{2}$ \\ Hui Wang' \\ 'School of Pharmacy, China Medical \\ University, Shenyang II000I, Liaoning, \\ China; ${ }^{2}$ Faculty of Medicine, Health \\ and Life Sciences, School of Pharmacy, \\ Queen's University Belfast, Belfast \\ BT9 7BL, Northern Ireland, UK \\ *These authors contributed equally \\ to this work
}

\begin{abstract}
Background: Antimicrobial peptides (AMPs) from the skin secretions of amphibians are now considered as a potential alternative to conventional antibiotics. Phylloseptins are a family of AMPs identified in the skin secretions of Phyllomedusinae tree frogs which exhibit highly conserved structural characteristics. This study examines the structure-activity relationship of the newly discovered phylloseptin, Phylloseptin-PHa (PSPHa) from Pithecopus hypochondrialis. Materials and methods: PSPHa and modified analogs were produced by solid phase synthesis and purified by reverse-phase HPLC. Rationally designed modified analogs incorporating changes in significant physicochemical parameters such as hydrophobicity, hydrophobic moment and net charge were investigated to determine their influence on secondary structure, antimicrobial activity, membrane permeabilization and cytotoxicity.
\end{abstract}

Results: Overall, we found that when rationally designing AMPs by altering their primary structure it is important to keep a balance between hydrophobicity and charge.

Conclusion: This study provides new insights which will help in the future development of AMPs as alternatives to conventional antibiotics for the treatment of Staphylococcus aureus and methicillin-resistant $S$. aureus infections.

Keywords: phylloseptin, antimicrobial activity, hydrophobicity, charge, membrane selectivity

\section{Introduction}

Over the past few years, it has become more difficult to treat many infections due to development of antibiotic resistance in many of the pathogenic bacteria responsible. Therefore, focusing on the discovery of new antimicrobial therapies to alleviate the pressures on conventional antibiotics is important to treat these infections. Antimicrobial peptides (AMPs) are considered as one of the best alternatives to conventional antibiotics due to the fact they are small molecules and they often have broad-spectrum antimicrobial activity as well as relatively low cytotoxicity. AMPs are ancient components of the innate immune system in all kingdoms of life, which represent the first line of defense to bacterial infections. ${ }^{1}$

Phylloseptins are a family of AMPs widely found in the skin secretions of Phyllomedusinae tree frogs. Members of this family of AMPs share several common features, such as 19 amino acids with C-terminal amidation, a highly-conserved N-terminal "FLSLIP" motif, a cationic amphiphilic structure, an $\alpha$-helical domain and they are rich in Lys/His amino acid residues. ${ }^{2}$ Phylloseptins also possess potent antimicrobial activity due to their disruption of the bacterial membrane. ${ }^{3}$ Indeed, it is speculated 
that these cationic peptides bind to the bacteria membrane surface due to the electrostatic attraction, and then adopt a helical amphipathic structure that promotes their insertion into the membrane, or they damage the bacterial membrane directly, compromising the bacterial membrane and causing their death. ${ }^{4}$

Phylloseptin-PHa (PSPHa) (Accession: SMY10434) is a member of the phylloseptin AMP family, which was previously identified from the skin secretions of Pithecopus (rectified from Phyllomedusa) hypochondrialis. ${ }^{5}$ It exhibited potent antimicrobial activity, but low hemolytic activity, suggesting it could represent a promising antimicrobial. In addition, although, 50 phylloseptins have been discovered so far, studies on their structure-activity relationship have been limited. Therefore, to further probe the structure-activity relationship of these AMPs, we investigated the influence of charges and hydrophobicity on the bioactivity of PSPHa, to further supplement our understanding of the phylloseptin family of AMPs.

\section{Materials and methods}

\section{Peptide synthesis}

Peptides were synthesized using Fmoc chemistry method as described previously. ${ }^{6}$ The cleavage cocktail contains trifluoroacetic acid (TFA)/ethanedithiol/thioanisole/water (94:2:2:2 [v/v]) for 2 hours at room temperature. The peptide was washed using cold diethyl ether and dissolved in $0.05 \%$ TFA/99.95\% water (v/v). Each peptide was purified by reverse-phase (RP) HPLC and structure verified by Matrix Assisted Laser Desorption/Ionization-Time of Flight Mass Spectrometry (MALDI-TOF).

\section{Comparison of hydrophobicity of peptides by RP-HPLC}

$0.5 \mathrm{mg}$ of each peptide was mixed and dissolved in $1 \mathrm{~mL}$ of $80 \%$ acetonitril/19.95\% water/0.05\% TFA (v/v) solution, and $10 \mu \mathrm{L}$ of mixture was injected into a C18 column (Columbus $5 \mu$ C18 110A 250×2.00 mm $5 \mu$ micro 197475-1) using Waters 1525 Binary HPLC Pump and Waters 2707 Autosampler. The peptides were eluted following the gradient: 0-10 minutes, 0\%-30\% ACN; 10-60 minutes, 30\%-95\% ACN. The flow rate was $0.2 \mathrm{~mL} / \mathrm{min}$, and the detection wavelength was $214 \mathrm{~nm}$. The elutes were collected and analyzed by MALDI-TOF.

\section{Prediction of physicochemical properties, secondary structures of peptides and circular dichroism (CD) analyses}

The predicted physicochemical properties (hydrophobicity, hydrophobic moment and net charges) and helical wheel projects of all peptides were obtained using Heliquest (http:// heliquest.ipmc.cnrs.fr/last accessed on September 06, 2018). The net charges were predicted at $\mathrm{pH}$ 7.4. The determination of secondary structure of peptides was conducted using a JASCO J-815 CD Spectropolarimeter (JASCO Inc., Tokyo, Japan) as described in the previous study. ${ }^{3}$ The $\mathrm{CD}$ spectrum was analyzed by BeStSel (http://bestsel.elte.hu/index.php last accessed on September 06,2018 ) for determination of $\alpha$-helix content.

\section{Antimicrobial assays}

The antimicrobial activity was evaluated by minimum inhibitory concentration and minimum bactericidal concentration assays using the broth-dilution method as described in the previous study. ${ }^{3}$ Seven different microorganisms were used in the assay: the Gram-positive bacteria Staphylococcus aureus (NCTC10788), Enterococcus faecalis (NCTC12697) and methicillin-resistant S. aureus (MRSA) (NCTC12493); the Gram-negative bacteria Escherichia coli (NCTC10418), Pseudomonas aeruginosa (ATCC27853) and Klebsiella pneumoniae (ATCC 43816); and the fungi Candida albicans (NCYC1467). All the strains were cultured in Mueller Hinton Broth (MHB), pH 7.4 (Oxiod, Basingstoke, UK). Each peptide was tested at the final concentration from 512 to 1 $\mu \mathrm{M}$ in twofold dilution. Hundred microliters of microorganism culture and sterilized MHB were applied as growth control and blank control, respectively. As the peptide stock solution was prepared in dimethyl sulfoxide (DMSO) and a $1 \%(\mathrm{v} / \mathrm{v})$ of DMSO was presented during the assays, additional test with $1 \%(\mathrm{v} / \mathrm{v})$ DMSO in the microorganism was applied as the vehicle control. The positive controls were applied as $5 \mathrm{mg} / \mathrm{L}$ vancomycin (Sigma-Aldrich, St. Louis, MO, USA) for Gram-positive bacteria, $5 \mathrm{mg} / \mathrm{L}$ gentamicin (Sigma-Aldrich) for Gram-negative bacteria and $5 \mathrm{mg} / \mathrm{L}$ amphotericin B (Sigma-Aldrich) for C. albicans.

\section{Membrane permeability assay}

Membrane permeability assay was conducted on $S$. aureus (NCTC10788) using the SYTOX ${ }^{\mathrm{TM}}$ Green Nucleic Acid Stain (Thermo Fisher Scientific, Waltham, MA, USA) as described previously, with some modifications. ${ }^{7}$ To obtain the fluorescence kinetics of membrane permeabilization, the bacterial suspension and peptide solutions were mixed to give a final concentration at $10 \mu \mathrm{M}$ in a black 96-well plate, the $5 \mu \mathrm{M}$ SYTOX Green nucleic acid stain was mixed with the reaction immediately. Then, the plate was read for 40 minutes (interval 5 minutes) directly without incubation and changes in membrane permeability were quantified via time-course analyses. All the peptides were prepared in 5\% Tryptic soy broth (TSB) (v/v) in $0.85 \% \mathrm{NaCl}$ solution $(\mathrm{m} / \mathrm{v})$ to achieve 
the final concentration of $10 \mu \mathrm{M}$. The total permeabilized cells of $S$. aureus were prepared by treating with $70 \%$ isopropanol and further resuspended in 5\% TSB/0.85\% NaCl solution after washing. The $S$. aureus cells resuspended in 5\% $\mathrm{TSB} / 0.85 \% \mathrm{NaCl}$ solution were used as the negative control. We also included the background control with SYTOX Green dye and $5 \% \mathrm{TSB} / 0.85 \% \mathrm{NaCl}$ solution only.

\section{MTT assay}

Cell viability was evaluated by MTT assay as described previously. ${ }^{7}$ Six cancer cell lines were purchased from the American Type Culture Collection (ATCC, Manassas, VA, USA) and Sigma-Aldrich, respectively, including melanocyte MDA-MB-435S (ATCC HTB-129), non-small-cell lung cancer NCI-H157 (ATCC CRL-5802), human prostate carcinoma PC-3 (ATCC CRL-1435), human colon cancer HCT116 (ATCC CCL-247), human breast cancer MCF-7 (ATCC HTB22) and human glioblastoma astrocytoma U251MG (ECACC General Cell Collection: 09063001). MDA-MB-435S, U251MG, HCT116 and MCF-7 were cultured in DMEM with $10 \% \mathrm{FBS}$ and $1 \%$ penicillin-streptomycin solution (Pen-Strep). The other cell lines were cultured in RPMI 1640 medium with 10\% FBS and 1\% Pen-Strep. All the peptide solutions were prepared in the serum-free culture medium, and the growth control was applied without any peptides.

\section{Lactate dehydrogenase (LDH) assay}

The cancer cell line MCF-7 (ATCC HTB-22) and nontumorigenic epithelial cell line MCF10A (ATCC CRL10317) were treated with PSPHa and the peptides at the concentration of $10 \mu \mathrm{M}$. The rate of $\mathrm{LDH}$ release from these two cell lines was measured using Pierce LDH Cytotoxicity Assay Kit (Thermo Fisher Scientific) based on the manufacturer's instruction. MCF-7 was cultured in DMEM with 10\% FBS and 1\% Pen-Strep. MCF10A was cultured in DMEM/ F12 (1:1) with 5\% horse serum, $20 \mathrm{ng} / \mathrm{mL}$ EGF, $100 \mathrm{ng} / \mathrm{mL}$ cholera toxin, $0.01 \mathrm{mg} / \mathrm{nL}$ insulin and $500 \mathrm{ng} / \mathrm{mL}$ hydrocortisone. Ten micromolars of each peptide were prepared in media. One percent (v/v) TritonX-100\% and 1\% PBS in media were employed as positive control and negative control, respectively.

\section{Hemolysis assay}

The hemolytic assay was performed by treating horse erythrocytes with a range of concentrations of the peptides from 512 to $1 \mu \mathrm{M}$ as described previously. ${ }^{3}$ All the peptides were prepared in PBS. The hemolysis of horse erythrocytes in PBS and 1\% (v/v) Triton-X100 was applied as $0 \%$ and $100 \%$ hemolytic controls, respectively. The half maximal hemolysis concentration $\left(\mathrm{HC}_{50}, \mu \mathrm{M}\right)$ was utilized to assess the hemolytic potential.

\section{Statistical analyses}

All experiments were repeated at least three times, and error bars represent the standard error of mean. Statistical analysis was performed using Unpaired $t$-test (GraphPad Prism 6.01, GraphPad Prism Inc., La Jolla, CA, USA).

\section{Results \\ Peptide design}

In this study, the natural peptide PSPHa was utilized as a template to design and synthesize a series of peptide analogs (Table 1). Briefly, Lys was applied to manipulate the cationicity and Ile was employed to adjust the hydrophobicity of peptides, respectively. To investigate the impact of charge, we substituted $\mathrm{Ala}^{7}$ with Lys to increase the presence of positive charge to form the analog PSPHa1. In addition, amino acid $\mathrm{Val}^{12}$ was replaced with Ile to form the analog PSPHa2, to study the effect of the motif "AISAIS" that is a typical motif in medusin family AMPs and is a $\alpha$-helical domain which will potentially increase its antimicrobial activity. ${ }^{8}$ Indeed, a previous study indicates the segment from positions 5 to 16 can already form a helical conformation in phylloseptin peptides. ${ }^{4}$ Furthermore, the amino acid Ala, ${ }^{14}$ on the hydrophobic face shown in Figure 1A, was replaced with Ile to increase the hydrophobicity in PSPHa3. In addition,

Table I The physiochemical properties of all peptides

\begin{tabular}{|c|c|c|c|c|c|}
\hline Peptide & Sequence & Hydrophobicity $<\mathbf{H}>$ & $\begin{array}{l}\text { Hydrophobic } \\
\text { moment }<\mu \mathrm{H}>\end{array}$ & $\begin{array}{l}\% \text { Helix } \\
\text { (TFE) }\end{array}$ & $\begin{array}{l}\text { Net charges } \\
\text { (pH 7.4) }\end{array}$ \\
\hline PSPHa & FLSLIPAAISAVSALANHF-NH & 0.799 & 0.457 & 41.0 & I \\
\hline PSPHal & FLSLIPKAISAVSALANHF-NH & 0.731 & 0.507 & 29.2 & 2 \\
\hline PSPHa2 & FLSLIPKAISAISALANHF-NH ${ }_{2}$ & 0.761 & 0.537 & 27.3 & 2 \\
\hline PSPHa3 & FLSLIPKAISAISALINHF-NH ${ }_{2}$ & 0.839 & 0.598 & 36.0 & 2 \\
\hline PSPHa4 & FLSLIPKIISAISALINHF-NH ${ }_{2}$ & 0.918 & 0.657 & 36.1 & 2 \\
\hline PSPHa5 & FLSLIPKIISAISALIKHF-NH & 0.897 & 0.673 & 40.5 & 3 \\
\hline
\end{tabular}

Notes: The hydrophobicity, hydrophobic moment and net charges were predicted by Heliquest online tool. The helical percentage was calculated from the CD spectra of each peptide in $50 \% \mathrm{TFE} / \mathrm{I} 0 \mathrm{mM} \mathrm{NH}_{4} \mathrm{AC}$ solution using BeStSel online software.

Abbreviations: CD, circular dichroism; PSPHa, Phylloseptin-PHa; TFE, 2,2,2-trifluoroethanol. 
A
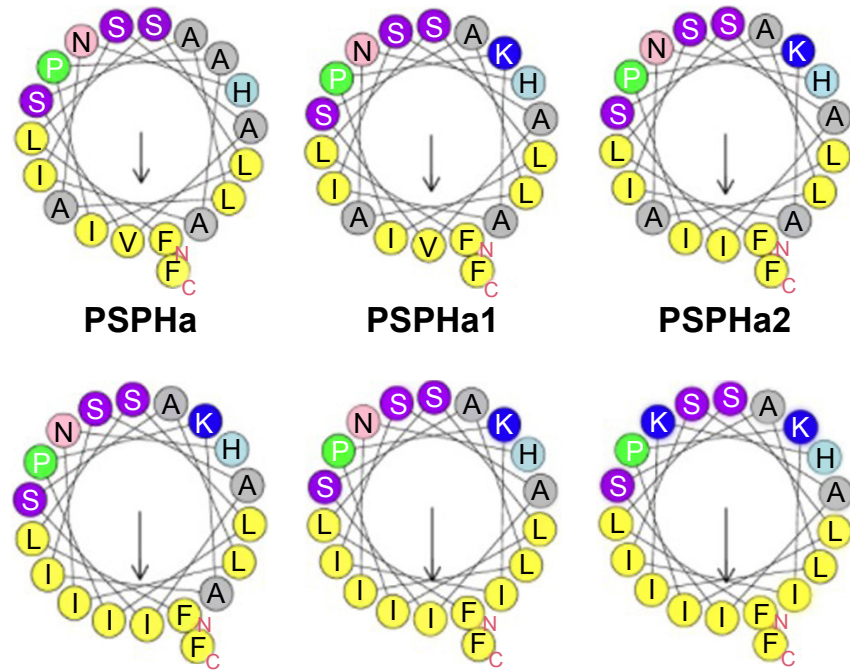

PSPHa3

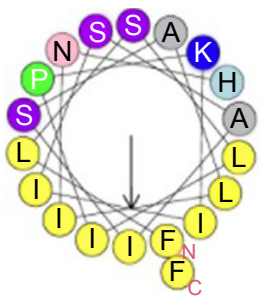

PSPHa4

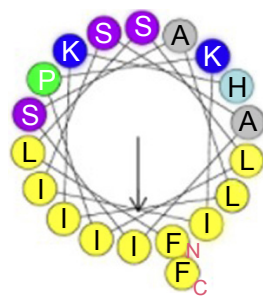

PSPHa5
B

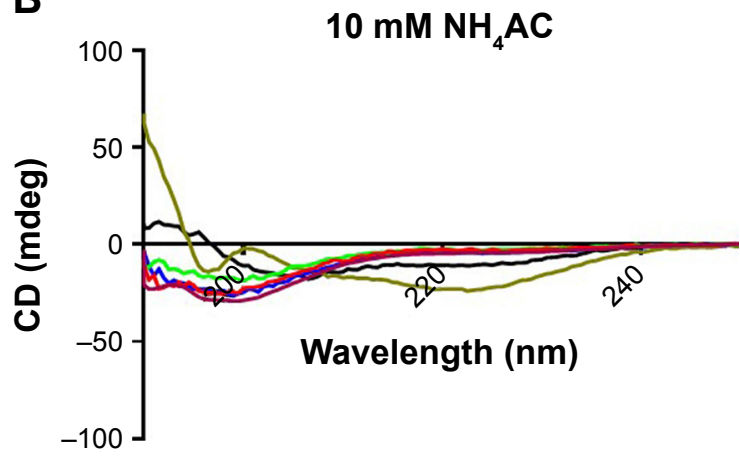

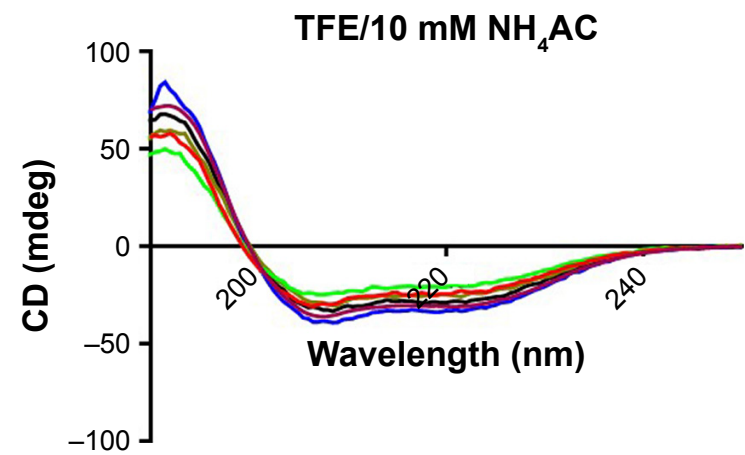

- $\mathrm{PSPHa}-\mathrm{PSPHa} 1-\mathrm{PSPHa} 2-\mathrm{PSPHa} 3-\mathrm{PSPHa} 4-\mathrm{PSPHa} 5$

Figure I The structural analysis of PSPHa and its analogs.

Notes: (A) The helical wheel of all peptides generated using Heliquest software. The arrows denote the direction of hydrophobic moment. (B) The CD spectra of all peptides in both $10 \mathrm{mM} \mathrm{NH}_{4} \mathrm{AC}$ solution and in $50 \%$ TFE/I0 mM NH $\mathrm{AC}_{4}$ solution at the concentration of $100 \mu \mathrm{M}$.

Abbreviations: CD, circular dichroism; PSPHa, Phylloseptin-PHa; TFE, 2,2,2-trifluoroethanol.

we substituted $\mathrm{Ala}^{8}$ in the hydrophobic face of PSPHa3 with Ile to make an analog (PSPHa4) with an intact and continuous hydrophobic face (Figure 1A). Finally, PSPHa5 was created by replacing $\mathrm{Asn}^{17}$ with Lys to produce a helix dipole that could extend the helical structure and potentially increase the antimicrobial activity. ${ }^{4}$

\section{Secondary structures analyses}

All the peptides exhibited $\alpha$-helical structures in the membranemimic environment with two negative bands in the CD spectra at 208 and $222 \mathrm{~nm}$ and a positive band at $193 \mathrm{~nm}$ (Figure 1B). However, PSPHa4 and PSPHa5 exhibited slightly negative ellipticity around $222 \mathrm{~nm}$ in $10 \mathrm{mM}$ ammonium acetate solution, indicating that both peptides formed the slight helical structures in the aqueous environment.
The calculated hydrophobicity, hydrophobic moment, net charge and the helicity of peptides in the membrane-mimic environment are shown in Table 1. Furthermore, the chromatogram demonstrated that the order of hydrophobicity of each peptide is $\mathrm{PSPHa} 4>\mathrm{PSPHa} 5>\mathrm{PSPHa} 3>\mathrm{PSPHa}>$ PSPHa2 $>$ PSPHa1 (Figure 2).

\section{Antimicrobial and hemolytic activities}

PSPHa and its analogs were assessed for antimicrobial activity against several Gram-positive, Gram-negative and fungi strains (Figure S1), and the results are summarized in Table 2. The parent peptide, PSPHa, had activity against $S$. aureus, C. albicans and MRSA but had no impact upon E. coli, E. faecalis, P. aeruginosa and $K$. pneumonia. The cationic-enhanced PSPHa1 displayed more potent 


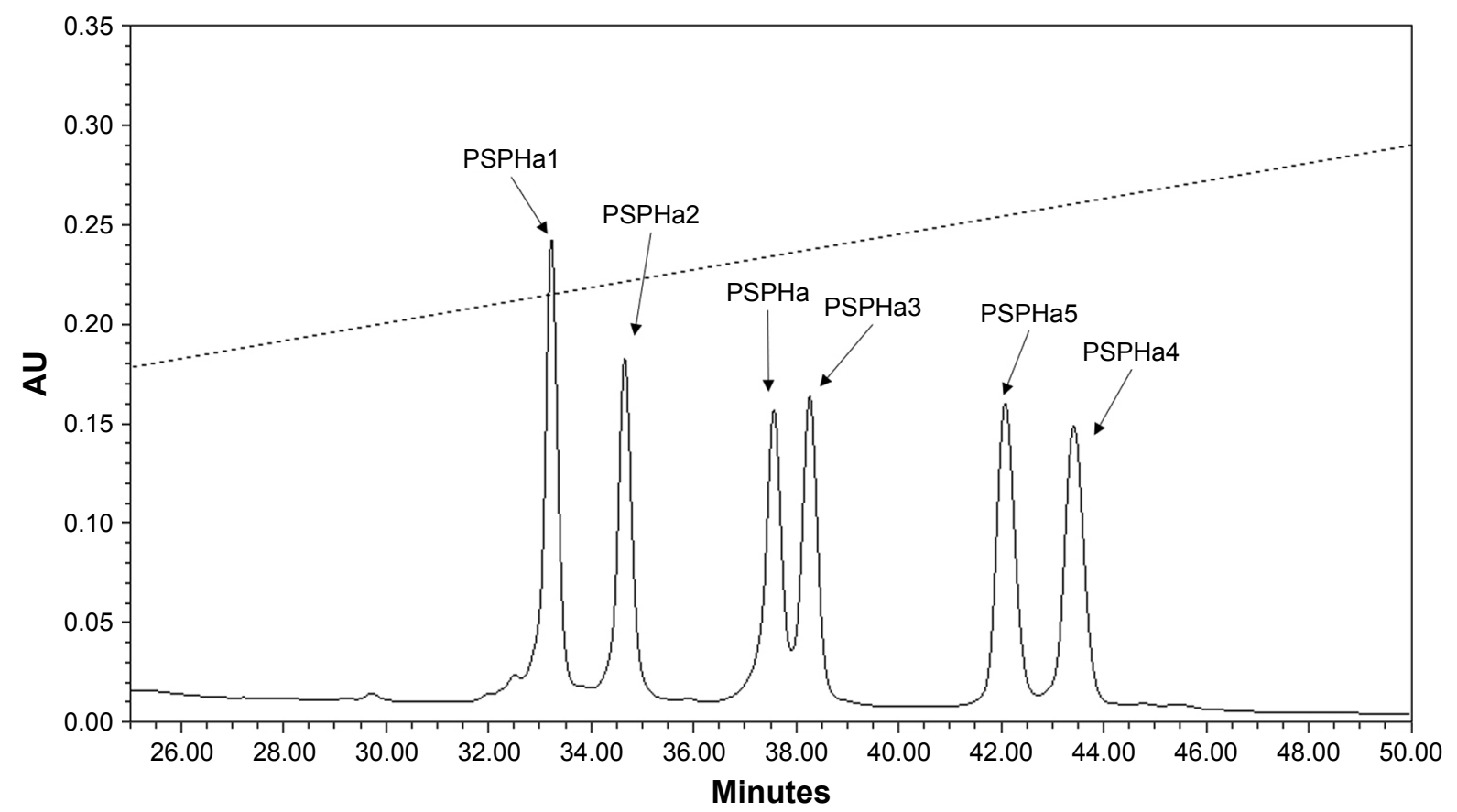

Figure 2 The region of reverse-phase HPLC chromatogram for all the peptides.

Notes: The retention time of each peptide is indicated by the arrows. The acetonitrile gradient is marked by a dotted line.

antimicrobial activity against $S$. aureus, $C$. albicans and MRSA, as well as activity against all the other microorganisms, except $P$. aeruginosa. PSPHa2 exhibited similar results to PSPHa1, but was more potent again against $S$. aureus, C. albicans, and slightly less potent toward E. faecalis. The hydrophobicity-enhanced PSPHa3 showed the strongest activity against the Gram-positive bacteria (S. aureus) and fungi (C. albicans), and also had activity against MRSA and E. faecalis, although it had no impact upon E. coli, $P$. aeruginosa and $K$. pneumonia. However, the most hydrophobic analog, PSPHa4, showed poorer activity than PSPHa3 against everything except $S$. aureus. Finally, PSPHa5 showed activity against $S$. aureus, $C$. albicans, MRSA and E. faecalis, but no impact upon E. coli, P. aeruginosa and K. pneumoniae. The hemolytic activities of these peptides were also assessed (Figure S2), and the $\mathrm{HC}_{50}$ values are summarized in Table 3. PSPHa had a relatively low hemolytic activity, and the cationic-enhanced PSPHa1 had a dramatically reduced activity in comparison. However, PSPHa2 exhibited more hemolytic activity than either of these and PSPHa3, PSPHa4 and PSPHa5 showed a dramatic drop in their $\mathrm{HC}_{50}$ values indicating significant hemolytic activity (Figure S3).

\section{Membrane permeabilization on S. aureus}

The ability of PSPHa and the analogs to permeabilize S. aureus were also examined, and the different peptides were

Table $2 \mathrm{MIC/MBC}$ of PSPHa and the analogs against selected microorganisms

\begin{tabular}{|c|c|c|c|c|c|c|}
\hline \multirow[t]{2}{*}{ Strains } & \multicolumn{6}{|c|}{ MIC/MBC $(\mu M)$} \\
\hline & PSPHa & PSPHal & PSPHa2 & PSPHa3 & PSPHa4 & PSPHa5 \\
\hline Staphylococcus aureus & $8 / 16$ & $8 / 8$ & $4 / 4$ & $2 / 2$ & $2 / 2$ & $2 / 2$ \\
\hline Escherichia coli & $>512 />512$ & $128 / 128$ & $64 / 128$ & $>5|2|>5 \mid 2$ & $>5 \mid 2 />512$ & $>512 />512$ \\
\hline Candida albicans & $32 / 32$ & $16 / 32$ & $8 / 16$ & $4 / 4$ & $32 / 128$ & $32 / 128$ \\
\hline MRSA & $64 / 128$ & $16 / 32$ & $16 / 32$ & $32 / 32$ & $128 / 256$ & $64 / 128$ \\
\hline Enterococcus faecalis & $>5 \mid 2 />512$ & $32 / 32$ & $64 / 64$ & $32 / 32$ & $32 / 64$ & $16 / 32$ \\
\hline Pseudomonas aeruginosa & $>5 \mid 2 />512$ & $>5 \mid 2 />512$ & $>5 \mid 2 />512$ & $>5|2 />5| 2$ & $>5 \mid 2 />512$ & $>512 />512$ \\
\hline Klebsiella pneumoniae & $>5 \mid 2 />512$ & $256 / 512$ & $256 / 512$ & $>5|2 />5| 2$ & $>5|2 />5| 2$ & $>512 />512$ \\
\hline
\end{tabular}

Abbreviations: $\mathrm{HC}_{50}$, half maximal hemolysis concentration; $\mathrm{MBC}$, minimum bactericidal concentration; $\mathrm{MIC}$, minimum inhibitory concentration; MRSA, methicillin-resistant S. aureus; PSPHa, Phylloseptin-PHa. 
Table 3 The $\mathrm{LD}_{50}$ of PSPHa and the analogs against selected human cancer cell lines using MTT assay and their respective $\mathrm{HC}_{50}$ on horse erythrocytes

\begin{tabular}{|l|l|l|l|l|l|l|}
\hline \multirow{2}{*}{ Cell lines } & \multicolumn{4}{l}{ LD $_{\mathbf{5 0}}$ of MTT assays $\left(\mathrm{HC}_{50}\right.$ of hemolysis on erythrocytes) $(\mu \mathrm{M})$} & \multicolumn{4}{l|}{} \\
\cline { 2 - 7 } & PSPHa & PSPHaI & PSPHa2 & PSPHa3 & PSPHa4 & PSPHa5 \\
\hline Erythrocytes & 52.17 & 197.7 & 34.86 & 9.266 & 2.766 & 1.074 \\
\hline MB435s & 28.48 & 32.41 & 19.56 & 3.994 & 4.802 & 3.553 \\
\hline HI57 & 37.61 & 41.73 & 35.34 & 2.865 & 2.265 & 3.614 \\
\hline PC-3 & 37.96 & 32.89 & 35.11 & 9.164 & 9.35 & 4.256 \\
\hline U25IMG & 34.67 & 33.65 & 36.46 & 10.85 & 9.547 & 4.059 \\
\hline HCTII6 & 36.64 & 35.16 & 37.4 & 11.71 & 6.779 & 4.421 \\
\hline MCF-7 & 24.05 & 45.69 & 26.49 & 10.48 & 15.01 & 3.753 \\
\hline
\end{tabular}

Abbreviations: $\mathrm{HC}_{50}$, half maximal hemolysis concentration; $\mathrm{PSPHa}$, Phylloseptin- $\mathrm{PHa}$.

found to exhibit dramatically different impacts when used at $10 \mu \mathrm{M}$ (Figure 3). PSPHa3-5 induced a rapid and total uptake of dye within a few minutes (Figure 3A), but the other three phylloseptins resulted in a low degree of membrane permeabilization and even after 2-hour incubation, $<30 \%$ of the $S$. aureus showed permeabilization (Figure 3).

\section{Cell viability}

PSPHa and its analogs were next assessed for any impact on the viability of selected cancer cell lines by MTT assays (Figure $\mathrm{S} 4$ ), and the median lethal dose $\left(\mathrm{LD}_{50}\right)$ results are summarized in Table 3. Generally, PSPHa, PSPHa1 and PSPHa2 exhibited similar impacts upon all the cancer cells examined, although PSPHa2 showed a slightly lower $\mathrm{LD}_{50}$ for MDAMB-435S cells. However, PSPHa3, PSPHa4 and PSPHa5 had dramatically lower $\mathrm{LD}_{50} \mathrm{~s}$ against all the cell lines, with the $\mathrm{LD}_{50}$ of PSPHa 5 being $<5 \mu \mathrm{M}$ for all the cell lines examined.

\section{LDH assay}

To further explore the impact of PSPHa and its analogs on cancer and normal cell viability, we next examined their impact upon the breast cancer cell line MCF-7 and the normal breast epithelial cell line MCF10A using the LDH assay (Figure 4). PSPHal induced the lowest degree of LDH release for both MCF-7 and MCF10A, and had a significantly greater impact upon the cancer cells. PSPHa2-5 exhibited potent effects on both the cancer and normal cells, suggesting they disrupt the cell membrane of both cell lines. PSPHa was not as potent as PSPHa2 -5 and induced a slightly more potent effect on MCF-7 than the normal breast cells.

\section{Discussion}

In the phylloseptin family, most members exhibit antimicrobial activity against a range of microorganisms, although they tend to be more potent against Gram-positive bacteria than the others. ${ }^{9}$ Indeed, PSPHa has antimicrobial activity against Gram-positive bacteria and fungi, while it shows no inhibitory activity against Gram-negative bacteria. Five analogs were designed and synthesized to investigate the structure-activity relationship of this peptide with the impact of cationicity, hydrophobicity and amphipathicity on its antimicrobial activity, membrane permeabilization and cytotoxicity.

Cationicity has been considered as the significant factor that ensures the electrostatic interaction between the negatively charged lipopolysaccharides and phospholipids on the cell membrane and the cationic peptides, ${ }^{10}$ although the impact of positive charge on the bioactivities of phylloseptins has been shown to depend on the balance with hydrophobicity. As observed in this study, enhanced cationicity increased the antimicrobial activity (PSPHa1 vs PSPHa; PSPHa5 vs PSPHa4). This indicates that the net positive charges of phylloseptins have an important role in regard to their antimicrobial activities, and that the positively charged Lys enhances binding of the peptide to the bacterial membrane ${ }^{11}$ In contrast, the peptide with the lowest hydrophobicity had the least impact upon cancer cell viability (PSPHa1), whereas the impact upon cancer cell viability was increased with higher hydrophobicity (PSPHa5). Therefore, while improving the charge status is beneficial to the electrostatic attraction to the anionic bilayer of the bacteria, it has less impact against the zwitterionic bilayer of mammalian cells. However, the permeabilization of mammalian cell membranes relies upon the hydrophobic interaction between the hydrophobic helix domain and the acyl domain of the cell membrane. ${ }^{12}$ In addition, improving the amphipathicity of the $\alpha$-helical structure can lead to a non-selective membrane disruption effect, ${ }^{13}$ illustrated by the increased activity of PSPHa5 against bacterial and mammalian cells. 

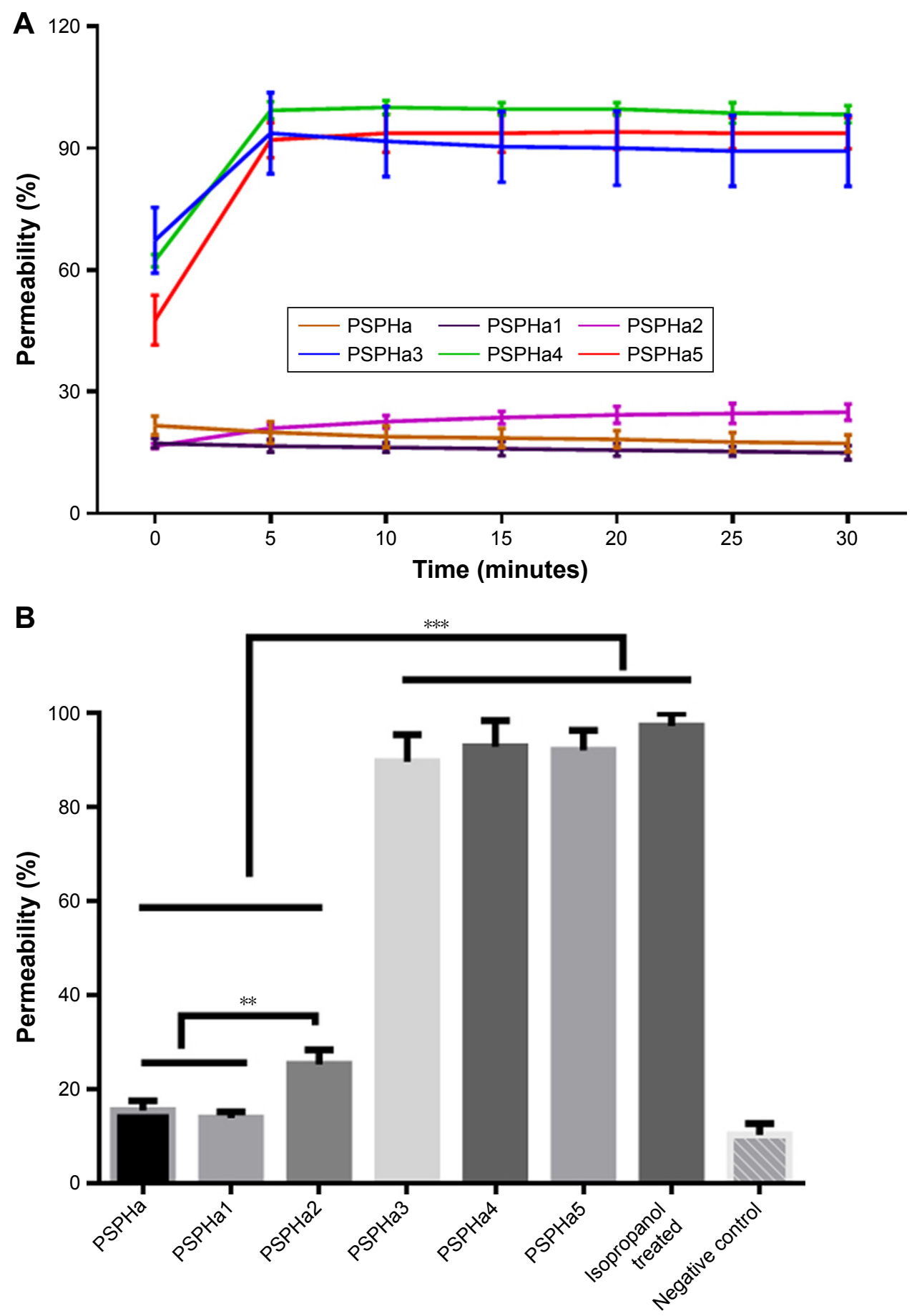

Figure 3 Membrane permeabilization of Gram-positive bacteria Staphylococcus aureus as indicated by an increase in the fluorescence of SYTOX Green dye.

Notes: (A) Kinetic dye uptake effect of PSPHa and the analogs against S. aureus at the concentration of $10 \mu \mathrm{M}$ over 30 minutes. (B) The end point of membrane permeabilization after 2 -hour incubation with $10 \mu \mathrm{M}$ of each peptide. The percentage was calculated by the uptake effect induced by $70 \%$ isopropanol-treated S. aureus. The negative control employed the dye uptake effect of untreated S. aureus suspension in $5 \% \mathrm{TSB} / 0.85 \% \mathrm{NaCl}$ solution. The error bar represents the SD, and all samples contained five replicates. The significance was calculated using unpaired $t$-test and indicated by $* * * P<0.01$ and $* * P<0.05$.

Abbreviation: PSPHa, Phylloseptin-PHa.

The overall hydrophobicity had a mixed impact upon the antimicrobial activity of these phylloseptins. As reported using transmission electron microscopy, phylloseptin kill S. aureus directly through disrupting the plasma membrane. ${ }^{14}$
Increased hydrophobicity does appear to correlate with increased activity against $S$. aureus, but this was not the case for the other strains. Indeed, as the hydrophobicity increased any impact upon E. coli and K. pneumoniae was lost, and the 


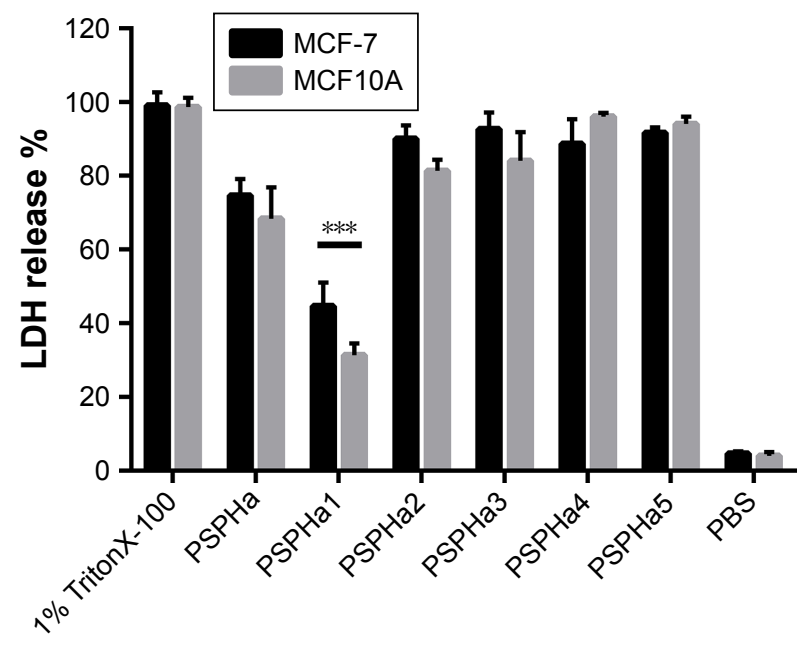

Figure $4 \mathrm{LDH}$ release from human breast cancer cell line MCF-7 and normal breast cell line MCFIOA induced at the concentration of $10 \mu \mathrm{M}$ of each peptide. Notes: The 100\% LDH release effect was induced by 1\% TritonX-100. The error bars represent the SD, and all samples had five replicates. The significance was calculated using unpaired $t$-test and indicated by $* * * P<0.01$.

Abbreviations: LDH, lactate dehydrogenase; PSPHa, Phylloseptin-PHa.

effects against $C$. albicans and MRSA did not appear to be dependent on the hydrophobicity.

As known, the lipopolysaccharide (LPS) layer of outer membrane of Gram-negative bacteria prevents the diffusion of hydrophobic molecules through the outer membrane, ${ }^{17}$ which protects the plasma membrane from permeabilization. Therefore, the very hydrophobic analogs could be blocked to reach the cell membrane by the LPS outer membrane, leading to the loss of antimicrobial effects of AMPs against Gram-negative bacteria.

Regarding Gram-positive bacteria, they possess a thick peptidoglycan layer that is cross-linked into a mesh-like framework. However, the thickness of the cell wall of Grampositive bacteria varies in different strains. It is reported that the antibiotic-resistant $S$. aureus possesses a thicker cell wall than normal $S$. aureus. ${ }^{18}$ In addition, the hydrophilicity of peptidoglycan may decrease the binding affinity between cell wall and hydrophobic peptides. This could explain why these phylloseptins demonstrated a lower antimicrobial activity against MRSA and E. faecalis which are more hydrophilic than $S$. aureus. Indeed, the highly hydrophobic analogs can disrupt $S$. aureus membrane integrity quickly and to a much greater extent than those with weaker hydrophobicity. Phylloseptins have been reported to adopt a helical structure and align parallel to the membrane, then they insert into the bilayer to form a transmembrane pore. ${ }^{19}$ The insertion of peptides depends on the hydrophobic interaction with acyl group of bilayers, therefore, the hydrophobic analogs could interact with the membrane more easily.

From another point, we observed that PSPHa5 and PSPHa4 did not have the random coil but the folded structures in the aqueous environment. The peptides containing alternating hydrophobic and hydrophilic amino acids promote the formation of peptide dimer due to the strong hydrophobic interaction, ${ }^{15}$ or generate the nanostructures, like nanofibers. ${ }^{16}$ Such superstructure makes obstacles for peptides to translocate from the cross-linked peptidoglycan in the cell wall of Gram-positive bacteria or the outer membrane of Gramnegative bacteria to the plasma cell membrane.

The cytotoxicity and hemolytic impact of the phylloseptins are regarded as the main obstacles to their development as new antimicrobials, ${ }^{20}$ and the hemolytic activity of the phylloseptins examined here is directly correlated with increasing hydrophobicity. We also noted that most naturally occurring phylloseptins exhibited different hemolytic activity and the significant hemolysis is only observed once the hydrophobicity is more than approximate 0.73 (Table 4). It indicates that the reduction of hemolysis of phylloseptin could be achieved if the hydrophobicity remains below that threshold. In addition, it has been shown that increasing net charge to +6 while the hydrophobicity is maintained under 0.73 could contribute to the enhanced antimicrobial activity without damaging the erythrocytes. ${ }^{3}$

PSPHa1 exhibited distinct effects between normal mammalian cells and cancer cells, which is consistent with the

Table 4 The physiochemical properties, antimicrobial activity and hemolytic activity of published naturally occurring phylloseptins

\begin{tabular}{|c|c|c|c|c|c|c|c|}
\hline \multirow[t]{2}{*}{ Peptide } & \multicolumn{3}{|l|}{ MIC $(\mu M)$} & \multirow{2}{*}{$\begin{array}{l}\text { Hydrophobicity } \\
<\mathbf{H}>\end{array}$} & \multirow{2}{*}{$\begin{array}{l}\text { Hydrophobic } \\
\text { moment }<\mu \mathrm{H}>\end{array}$} & \multirow{2}{*}{$\begin{array}{l}\text { Net charges } \\
\text { (pH 7.4) }\end{array}$} & \multirow[t]{2}{*}{$\mathrm{HC}_{50}$} \\
\hline & $\begin{array}{l}\text { Staphylococcus } \\
\text { aureus }\end{array}$ & $\begin{array}{l}\text { Escherichia } \\
\text { coli }\end{array}$ & $\begin{array}{l}\text { Candida } \\
\text { albicans }\end{array}$ & & & & \\
\hline PSN-PC ${ }^{20}$ & 2 & 8 & 2 & 0.754 & 0.563 & +2 & 23 \\
\hline PS-PTa ${ }^{5}$ & 4.1 & 16.6 & 2.1 & 0.740 & 0.577 & +2 & 22.8 \\
\hline PS-Du ${ }^{23}$ & 3.90 & 62.5 & 7.8 & 0.725 & 0.624 & +2 & 95 \\
\hline PS-PBa ${ }^{22}$ & 4.2 & 67.6 & 4.2 & 0.711 & 0.637 & +2 & 90 \\
\hline $\mathrm{PS}-\mathrm{Co}^{23}$ & 4.1 & 64.9 & 8.1 & 0.706 & 0.636 & +2 & 115 \\
\hline PS-PT ${ }^{3}$ & 264 & $>264$ & 264 & 0.707 & 0.418 & +2 & $>264$ \\
\hline
\end{tabular}

Abbreviations: $\mathrm{HC}_{50}$, half maximal hemolysis concentration; MIC, minimum inhibitory concentration. 
hypothesis that AMPs specifically recognize the negatively charged surface of cancer cells and that such interactions may involve the overexpressed $O$-glycosylated mucins, or alterations in the carbohydrate portion of glycoproteins and glycolipids, including increased sialylation and the presence of glycosaminoglycans. ${ }^{21}$ These results would also indicate that maintaining the hydrophobicity of phylloseptins around 0.73 and increasing the net positive charge could be an appropriate approach to improve the potential therapeutic properties of these phylloseptins.

In summary, our study revealed the specific structureactivity relationship in regard to the charge and hydrophobicity of phylloseptins. Increasing the hydrophobicity, particularly on the hydrophobic face, correlated with enhanced membrane permeabilization, whereas increasing the charge when the hydrophobic range was low, benefited the selectivity. Therefore, it is feasible to design a peptide which not only possesses a broad-spectrum antimicrobial activity but also exhibits negligible cytotoxicity, as an alternative to conventional antibiotics.

\section{Acknowledgment}

This work was supported by grants from the National Nature Science Foundation of China (No 81703572 to QD and No 81702611 to HW).

\section{Author contributions}

All authors contributed to data analysis, drafting and revising the article, gave final approval of the version to be published, and agree to be accountable for all aspects of the work.

\section{Disclosure}

The authors report no conflicts of interest in this work.

\section{References}

1. Ebbensgaard A, Mordhorst H, Overgaard MT, Nielsen CG, Aarestrup FM, Hansen EB. Comparative evaluation of the antimicrobial activity of different antimicrobial peptides against a range of pathogenic bacteria. PLoS One. 2015;10(12):e0144611.

2. Wu D, Gao Y, Wang L, et al. A combined molecular cloning and mass spectrometric method to identify, characterize, and design frenatin peptides from the skin secretion of Litoria infrafrenata. Molecules. 2016; 21(11): 1429 .

3. Gao Y, Wu D, Xi X, et al. Identification and characterisation of the antimicrobial peptide, Phylloseptin-PT, from the skin secretion of Phyllomedusa tarsius, and comparison of activity with designed, cationicity-enhanced analogues and diastereomers. Molecules. 2016;21(12):1667.

4. Resende JM, Moraes CM, Prates MV, et al. Solution NMR structures of the antimicrobial peptides phylloseptin-1, -2 , and -3 and biological activity: the role of charges and hydrogen bonding interactions in stabilizing helix conformations. Peptides. 2008;29(10):1633-1644.

5. Liu J, Wu Q, Li L, et al. Discovery of phylloseptins that defense against Gram-positive bacteria and inhibit the proliferation of the non-small cell lung cancer cell line, from the skin secretions of Phyllomedusa frogs. Molecules. 2017;22(9):1428.
6. Zhang L, Chen X, Zhang Y, et al. Identification of novel Amurin-2 variants from the skin secretion of Rana amurensis, and the design of cationicity-enhanced analogues. Biochem Biophys Res Commun. 2018; 497(4):943-949.

7. Huang L, Chen D, Wang L, et al. Dermaseptin-PH: a novel peptide with antimicrobial and anticancer activities from the skin secretion of the South American Orange-Legged leaf frog, Pithecopus (Phyllomedusa) hypochondrialis. Molecules. 2017;22(10):1805.

8. Xi X, Li R, Jiang Y, et al. Medusins: a new class of antimicrobial peptides from the skin secretions of phyllomedusine frogs. Biochimie. 2013;95(6):1288-1296.

9. Gao Y, Wu D, Wang L, et al. Targeted modification of a novel amphibian antimicrobial peptide from Phyllomedusa tarsius to enhance its activity against MRSA and microbial biofilm. Front Microbiol. 2017; 8:628.

10. Jiang Z, Vasil AI, Hale JD, Hancock RE, Vasil ML, Hodges RS. Effects of net charge and the number of positively charged residues on the biological activity of amphipathic alpha-helical cationic antimicrobial peptides. Biopolymers. 2008;90(3):369-383.

11. Lee JK, Park SC, Hahm KS, Park Y. Antimicrobial HPA3NT3 peptide analogs: placement of aromatic rings and positive charges are key determinants for cell selectivity and mechanism of action. Biochim Biophys Acta. 2013;1828(2):443-454.

12. Dathe M, Schümann M, Wieprecht T, et al. Peptide helicity and membrane surface charge modulate the balance of electrostatic and hydrophobic interactions with lipid bilayers and biological membranes. Biochemistry. 1996;35(38):12612-12622.

13. Mihajlovic M, Lazaridis T. Charge distribution and imperfect amphipathicity affect pore formation by antimicrobial peptides. Biochim Biophys Acta. 2012;1818(5):1274-1283.

14. Nacif-Marçal L, Pereira GR, Abranches MV, et al. Identification and characterization of an antimicrobial peptide of Hypsiboas semilineatus (Spix, 1824) (Amphibia, Hylidae). Toxicon. 2015;99:16-22.

15. Chen Y, Guarnieri MT, Vasil AI, Vasil ML, Mant CT, Hodges RS. Role of peptide hydrophobicity in the mechanism of action of alpha-helical antimicrobial peptides. Antimicrob Agents Chemother. 2007;51(4): 1398-1406.

16. Mandal D, Nasrolahi Shirazi A, Parang K. Self-assembly of peptides to nanostructures. Org Biomol Chem. 2014;12(22):3544-3561.

17. Nikaido H. Molecular basis of bacterial outer membrane permeability revisited. Microbiol Mol Biol Rev. 2003;67(4):593-656.

18. García AB, Viñuela-Prieto JM, López-González L, Candel FJ. Correlation between resistance mechanisms in Staphylococcus aureus and cell wall and septum thickening. Infect Drug Resist. 2017;10:353-356.

19. Resende JM, Verly RM, Aisenbrey C, et al. Membrane interactions of phylloseptin-1, -2 , and -3 peptides by oriented solid-state NMR spectroscopy. Biophys J. 2014;107(4):901-911.

20. Wu X, Pan J, Wu Y, et al. PSN-PC: a novel antimicrobial and antibiofilm peptide from the skin secretion of Phyllomedusa camba with cytotoxicity on human lung cancer cell. Molecules. 2017;22(11):1896.

21. dos Santos C, Hamadat S, Le Saux K, et al. Studies of the antitumor mechanism of action of dermaseptin B2, a multifunctional cationic antimicrobial peptide, reveal a partial implication of cell surface glycosaminoglycans. PLoS One. 2017;12(8):e0182926.

22. Wan Y, Ma C, Zhou M, et al. Phylloseptin-PBa - a novel broadspectrum antimicrobial peptide from the skin secretion of the Peruvian purple-sided leaf frog (Phyllomedusa baltea) which exhibits cancer cell cytotoxicity. Toxins. 2015;7(12):5182-5193.

23. Yang N, Li L, Wu D, et al. Discovery of novel bacterial cell-penetrating Phylloseptins in defensive skin secretions of the South American Hylid frogs, Phyllomedusa duellmani and Phyllomedusa coelestis. Toxins. 2016;8(9):255. 


\section{Supplementary materials}
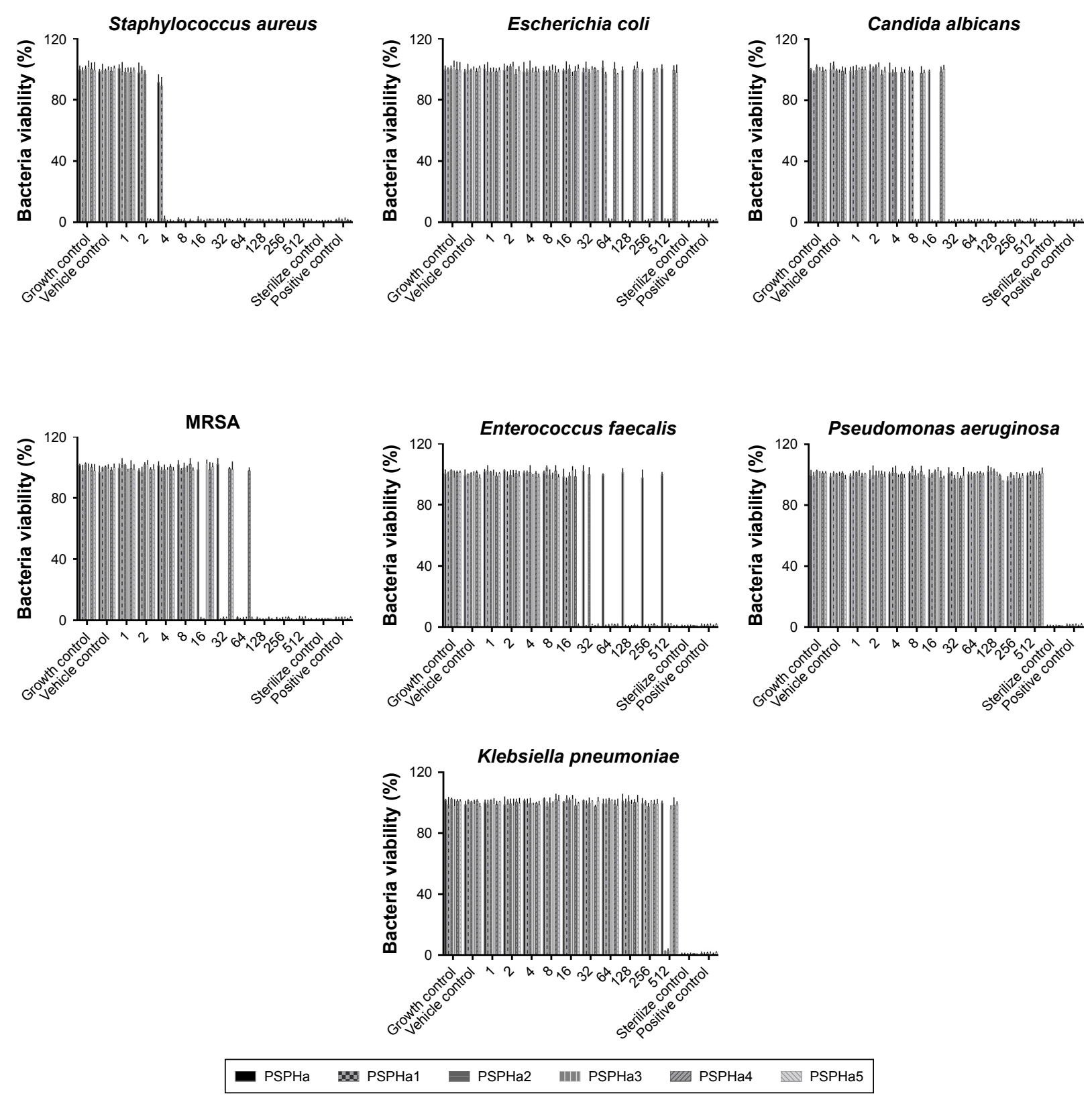

Figure SI The antimicrobial activity of each peptide against the selected microorganisms from 5 I 2 to I $\mu$ M.

Notes: The growth control was presented as bacteria culture without peptides. The vehicle control was employed a final concentration of I\% (v/v) DMSO. The sterilize control employed fresh MHB. The positive controls were applied as $5 \mathrm{mg} / \mathrm{L}$ vancomycin for Gram-positive bacteria, $5 \mathrm{mg} / \mathrm{L}$ gentamicin for Gram-negative bacteria and $5 \mathrm{mg} / \mathrm{L}$ amphotericin B for C. albicans. Bars show the mean and the error bars show the standard error from five independent experiments.

Abbreviations: DMSO, dimethyl sulfoxide; MHB, Mueller Hinton Broth; MRSA, methicillin-resistant S. aureus; PSPHa, Phylloseptin-PHa. 


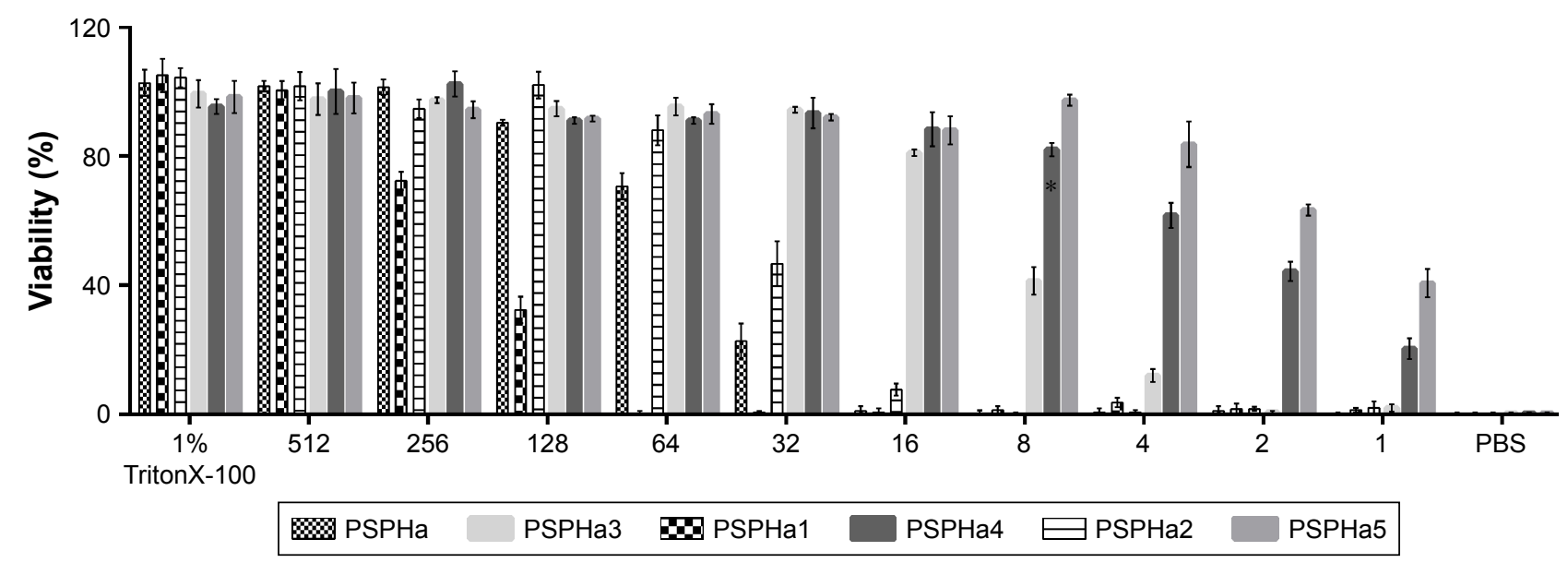

Figure S2 The hemolytic activity of each peptide on horse erythrocytes from 512 to $1 \mu \mathrm{M}$.

Notes: I\% TritonX-100 and PBS were employed as positive control and negative control, respectively. Bars show the mean and the error bars show the standard error from five independent experiments.

Abbreviation: PSPHa, Phylloseptin-PHa.

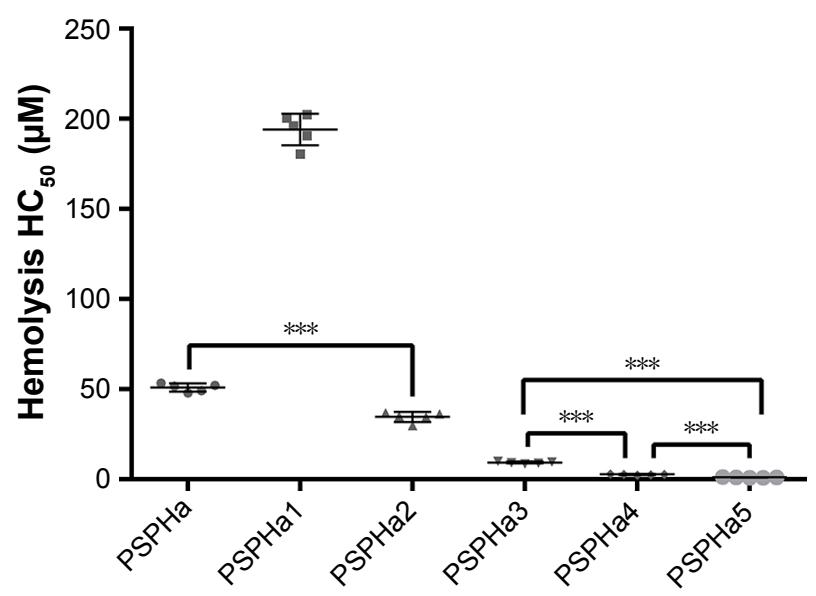

Figure S3 The $\mathrm{HC}_{50}$ of each peptide on horse erythrocytes.

Notes: Bars show the mean and the error bars show the standard error from five independent experiments. $P$-value was calculated using unpaired $t$-test, indicating significance $* * * P<0.001$.

Abbreviations: $\mathrm{HC}_{50}$, half maximal hemolysis concentration; PSPHa, Phylloseptin- $\mathrm{PHa}$. 


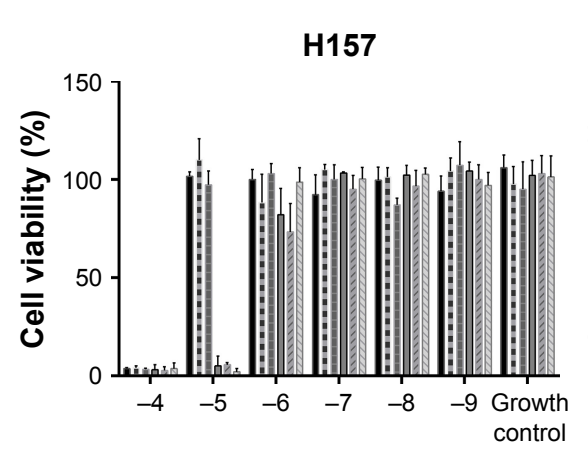

Log [peptide] (M)

MB435s

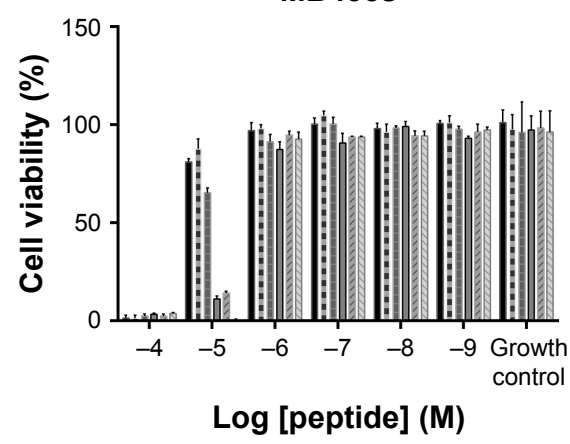

PC-3

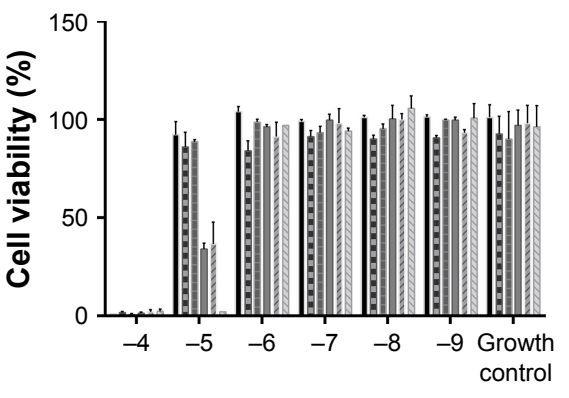

Log [peptide] (M)

U251MG

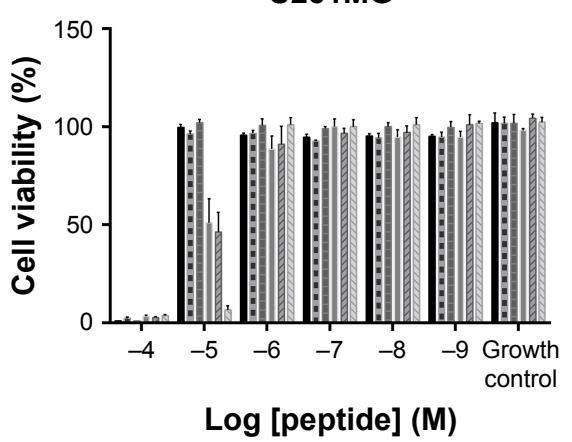

HCT116

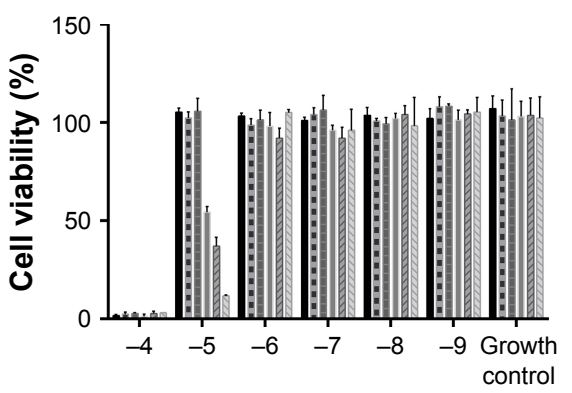

Log [peptide] (M)

MCF-7

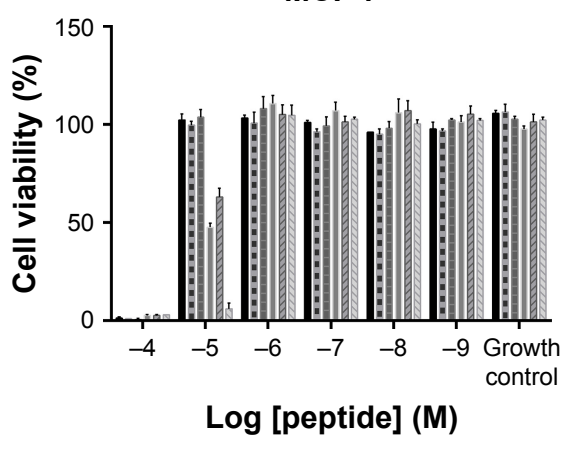

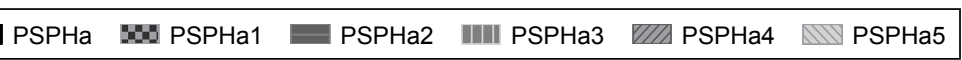

Figure S4 The MTT assays of each peptide against the selected cancer cell lines.

Notes: The cell viability of growth control (cell growth without peptides) was applied as $100 \%$ cell viability. Bars show the mean and the error bars show the standard error from five independent experiments.

Abbreviation: PSPHa, Phylloseptin-PHa.

\section{Publish your work in this journal}

Drug Design, Development and Therapy is an international, peerreviewed open-access journal that spans the spectrum of drug design and development through to clinical applications. Clinical outcomes, patient safety, and programs for the development and effective, safe, and sustained use of medicines are the features of the journal, which has also been accepted for indexing on PubMed Central. The manuscript management system is completely online and includes a very quick and fair peer-review system, which is all easy to use. Visit http://www.dovepress.com/testimonials.php to read real quotes from published authors 